\title{
Carbon Sequestration in Soil as a Sustainable Way of Greenhouse Effect Mitigation
}

\section{Sekwestracja węgla w glebie jako zrównoważona metoda ograniczania efektu cieplarnianego}

\section{Grażyna Żukowska*1, Magdalena Myszura*2, Magdalena Zdeb**3, Małgorzata Pawłowska**4}

\author{
*University of Life Science in Lublin, Faculty of Agrobioengineering, Institute of Soil Science \\ and Environment Management, Leszczyńskiego 7, 20-069 Lublin, Poland \\ **Lublin University of Technology, Faculty of Environmental Engineering, Nadbystrzycka \\ 40B, 20-710 Lublin, Poland \\ E-mail (coresponding author): magdalena.myszura@up.lublin.pl \\ ORCID $^{1}$ :0000-0002-8189-6675, ORCID ${ }^{2}: 0000-0002-5378-924 X$ \\ ORCID ${ }^{3}:$ 0000-0002-9337-0830, ORCID ${ }^{4}: 0000-0002-5976-7420$
}

\begin{abstract}
Due to natural mechanisms of transformation the carbon compounds contained in the atmosphere into the humus, soil is an important factor controlling the concentration of atmospheric $\mathrm{CO}_{2}$. The mass of carbon contained in organic matter accumulated in the surface layer of the Earth's crust is greater than the mass of this element in the atmosphere or biomass of all the organisms living over the globe. Over the recent years, much attention has been paid to the role of soils in limiting the reasons of climate changes, considering the possibility of increasing carbon sequestration in this matrix. This way of approaching the problem of the greenhouse effect, which does not require an involvement of complex and expensive technological solutions aimed at capturing and storing the atmospheric $\mathrm{CO}_{2}$, and additionally contributing to improving the quality of soil and water environment, and soil productivity is fully sustainable and combines the environmental, economic and social issues.
\end{abstract}

Key words: climate change, soil functions, carbon cycle

\section{Streszczenie}

Dzięki istnieniu naturalnych mechanizmów transformacji związków węgla zawartych w atmosferze w związki próchniczne, gleba stanowi istotny czynnik kontrolujący stężenie atmosferycznego $\mathrm{CO}_{2}$. Masa węgla zawartego w materii organicznej nagromadzonej w powierzchniowej warstwie skorupy ziemskiej jest większa niż masa tego pierwiastka $\mathrm{w}$ atmosferze lub biomasie organizmów żywych. W ostatnich latach wiele uwagi poświęca się roli gleb w ograniczeniu przyczyn zmian klimatycznych, poddając pod rozwagę możliwości zwiększenia w nich sekwestracji węgla. Taki sposób podejścia do problemu efektu cieplarnianego, nie wymagający wprowadzania złożonych i drogich rozwiązań technologicznych nakierowanych na wychwytywanie i magazynowanie atmosferycznego $\mathrm{CO}_{2}$, a dodatkowo przyczyniający się do poprawy jakości środowiska gruntowo-wodnego oraz produktywności gleb jest w pełni zrównoważony, gdyż łączy ze sobą zarówno kwestie środowiskowe, gospodarcze i społeczne.

Słowa kluczowe: zmiany klimatyczne, funkcje gleby, obieg węgla

\section{Introduction}

The data of the International Panel on Climate Change indicate that the annual global greenhouse gas (GHG) emissions have been rising since the Industrial Revolution (IPCC, 2013). The main factors increasing the anthropogenic greenhouse gas emissions are population growth, economic growth, fos- 
sil fuel consumption and land use change. The increase in GHG emissions in the years 1970-2000 was about 1.3\%/year, and in the years 2000-2010, $2.2 \% / y e a r$. Carbon dioxide has the largest share in the total greenhouse gas pool $-65 \%$ of the $\mathrm{CO}_{2}$ emissions come from the combustion of fossil fuels and industrial processes, while $11 \%$ from agriculture and forestry (IPCC, 2013).

The consequences of growing greenhouse gas emissions are the effects of climate change, including the changes of the weather patterns, rising sea levels and extreme weather phenomena. According to the IPCC (2018) if the current level of concentration and the amount of greenhouse gas emissions are maintained, the temperature on Earth at the end of this century will rise by more than $1.5^{\circ} \mathrm{C}$, compared to 1850 1900. At the same time, the ocean water temperature will rise and the ice cover will still be melting. It is estimated that the average sea level will increase by $24-30 \mathrm{~cm}$ by 2065 and by $40-63 \mathrm{~cm}$ by 2100 . Most of the climate change effects will persist for centuries, even if the greenhouse gas emissions can be stopped.

This is one of the most important challenges from the perspective of sustainable development, since consequences of climate change will touch all the people in every country. That's why among 17 most important Sustainable Development Goals, introduced by the UN in 2015, we can find goal named Climate action, which is calling all societies to fight global warming.

In order to reduce and/or mitigate the potential negative effects of temperature rise on ecosystems and the economy, it is necessary to take the measures to reduce the concentration of $\mathrm{CO}_{2}$ in the atmosphere. The main strategies that can be used for this purpose are: reduction of global $\mathrm{CO}_{2}$ emissions to the atmosphere, development of the alternatives to the fossil fuels as well as carbon capture and its long-term storage in geological formations, oceans and terrestrial ecosystems (Olejnik \& Sobiecka, 2017).

Carbon sequestration in terrestrial ecosystems includes $\mathrm{CO}_{2}$ storage in plant biomass and soils. These processes are referred to as phytosequestration and soil carbon sequestration, respectively (Post and Kwan, 2000). In terrestrial ecosystems, carbon storage occurs mainly through the photosynthesis, as well as in the form of soil organisms and dead organic matter. Lal (2008) described several scenarios for the carbon sequestration in terrestrial ecosystems, which include soils, grasslands, forests and wetlands. Soil ability to store carbon is greater than that of plants and the atmosphere (Cel et al., 2016). By maintaining this huge amount of carbon, the soil prevents or delays the accumulation of carbon dioxide in the atmosphere. On the other hand, even a small increase in the soil carbon content, can have a significant impact on the overall carbon $\left(\mathrm{CO}_{2}\right)$ balance in the environment (IPCC, 2000). According to European Environmental Agency (EEA, 2019) healthier soils and a sustainable land and soil management, are the necessary conditions to deal with climate crisis, produce enough food and adapt to a changing climate.

\section{Soil role in the carbon cycle}

Soil is a major component of the terrestrial ecosystem (Banwart et al., 2017), which comprises the surface part of lithosphere transformed by physical, chemical and biological processes. Soil is still weakly understood matrix which plays a an essential functions for the global ecosystems (Balestrini et al., 2015). However, the importance of soil role in the ecosystems cannot be overestimated, which was emphasized by the initiator of the Polish pedologic school prof. Sławomir Miklaszewski (1907) in the sentence that can be translated: There is no soil without life, nor life without soil (cited by Dobrzański \& Zawadzki, 2005). Biomass production, matter cycling, habitat for biological activity, filter and buffer for water and carbon sequestration are the main soil function in terrestrial ecosystems (Banwart et al., 2017). The latter can be considered a key soil function for climate regulation, as well as plays a crucial role in regulating the soil's ability to perform other environmental functions (Weismeier et al., 2019).

The soil is the largest terrestrial carbon reservoir estimated at about 2,344 Gt of organic carbon retained in the layer up to $3 \mathrm{~m}, 1,500 \mathrm{Gt}$ in the layer up to $1 \mathrm{~m}$ and $615 \mathrm{Gt}$ stored in the upper $20 \mathrm{~cm}$ layer of the soil profile (Stockmann et al., 2013). This is accounts for $80 \%$ of carbon resources in terrestrial ecosystems. Stockmann et al. (2013) report that the amount of $\mathrm{CO}_{2}$ emitted into the atmosphere annually is estimated at $8.7 \mathrm{GtC}$, while only $3.8 \mathrm{Gt}$ of $\mathrm{CO}_{2}$ remains in the atmosphere during the year. This leaves an outstanding balance of $4.9 \mathrm{Gt}$ C/year, which is believed to be retained in land and sea systems (forests, soils, oceans, etc.). The researchers indicate that soil can be considered as the key $\mathrm{CO}_{2}$ storage system that can provide the necessary climate regulation services. Understanding the role of terrestrial systems, including soil, in the carbon cycle caused that the special attention was paid to the potential of these systems for carbon sequestration and storage (Post and Kwon, 2000). It should also be noted that the organic carbon stored in soils may undergo mineralization, as a result of which significant amounts of $\mathrm{CO}_{2}$ are released into the atmosphere (Weismeier et al., 2019). In addition, the binding of $\mathrm{CO}_{2}$ in soil leads to an increase in the humus content, which will bring additional benefits, among others: improvement of the physical, chemical and biological properties of soils. For example, the improvement of water properties and the sorption capacity of the soil enable to increase the amount of water and ions available to plants and binding the pollutants. As a consequence, primary biomass production will increase, and more $\mathrm{CO}_{2}$ will be absorbed from the atmosphere. 
A larger inflow of plant biomass will provide an additional substrate for the newly formed humus compounds (Weismeier et al., 2019).

Soil carbon sequestration was defined by Olson (2013) as a process of transferring the atmospheric $\mathrm{CO}_{2}$ into the soil through plants, plant residues, and other organic solids in order to be retained in the soil organic matter (humus). According to the Soil Science Society of America, sequestration involves storing carbon in a stable solid form in soil as a result of direct and indirect atmospheric binding of $\mathrm{CO}_{2}$ (Burras et al., 2001). Direct binding relies on the natural conversion of $\mathrm{CO}_{2}$ into inorganic compounds in soil, such as calcium and magnesium carbonates. Indirect sequestration occurs when plants produce biomass through photosynthesis. This biomass is ultimately transferred to the soil and, after decomposition, indirectly sequestered as an organic soil substance. The amount of sequestered carbon in soil reflects the long-term balance between the $\mathrm{CO}_{2}$ uptake and release mechanisms (Lal, 2008).

According to ICPC (2013), agricultural soils have a sequestration potential of up to $1.2 \mathrm{Gt}$ of carbon per year, but it is also estimated that around $50 \%$ of agricultural soils have already been degraded around the world, which suggest that there is the chance for increasing carbon sequestration in these soils by their reclamation. Since the time when the natural ecosystems were started to be transformed to agroecosystems, the soil organic carbon stocks have declined by an average of 30-55\% (Batjes, 2013). Implementation of a carbon sequestration strategy in soil should enable recovering 50-60\% of the original soil carbon content, leading to the restoration of productivity of agricultural and degraded land (Lal, 2004). Hansen et al. (2013) indicate that arable land could sequester at least $10 \%$ of the current annual $\mathrm{CO}_{2}$ emissions, which are estimated at 8-10 Gt/yr. Thus, taking into account the global carbon cycle soil plays an ambiguous role in the emission of greenhouse gases, being the emitter and absorber simultaneously. Finally, the role of soils in mitigation the climate change depends on the balance of emissions and retention of greenhouse gases. This balance is determined by many factors, including the properties of soil and organic matter reaching it, climatic conditions, as well as the method of cultivation and fertilization.

\section{Factors influencing the content and quality of soil organic matter}

From a geological point of view, sequestration is the binding of $\mathrm{CO}_{2}$ over a very long time scale. From the point of view of human time scale, the carbon binding in soil in a form of mineralization-resistant compounds can be treated as sequestration. The humus compounds characterized by a complex structure, and the humus bound in organic-mineral connections (these connections are considered as the basic mechanism for protecting the humus against mineralization) are deemed to be permanently carbon binding compounds. The binding of carbon in the biomass of soil microorganisms is also important. Despite its low durability, the dead cells are the substrate for formation of humus compounds.

The condition of humus in soils is determined by many factors, while the quantity and quality of humus have a significant impact on the basic soil properties that determine their fertility (Goh, 2004). The main factors affecting the content of organic matter in soil include environmental factors, such as types of climate and plant cover, and soil properties (Chabbi et al., 2009) - and in the soil under cultivation - also the anthropogenic factors, including the way of land use, cultivation systems (Wiesmeier et al., 2013), fertilization (Kundu et al., 2007) and degradation processes (Lal, 2004).

The course of soil-forming processes and plant growth are mainly dependent on the climate, including the temperature and amount of precipitation. Precipitation determines the net primary productivity and thus the amount of plant residues flowing into the soil. In addition, humid conditions may intensify the weathering of primary minerals, which promotes the formation of mineral surfaces stabilizing soil organic carbon (Doetterl et al., 2015). Temperature significantly affects the degradation of organic matter by the microorganisms that are highly sensitive to temperature (Conant et al., 2011, Davidson and Janssens, 2006). Numerous studies indicate a decrease in soil organic carbon (SOC) content with increasing temperatures (Jobbagy and Jackson, 2000; Koven et al., 2017). In general, the soils in humid and cool climate zones are characterized by the highest content of organic C. According to Dixon et al. (1994), $58 \%$ of $787 \mathrm{Pg}$ of carbon contained in the forest ecosystems is accumulated in the forests located in the climate zones characterized by a relatively cool and humid climate. Moving from a colder to warmer climate conditions, the content of organic matter in the soils of comparable types decreases, which is caused by an increase in the mineralization rate with the growth of the temperature. It is estimated that in comparable soil types and environmental conditions, along with a decrease in temperature by $10^{\circ} \mathrm{C}$, the content of organic matter increases $2-3$ times (Koven et al., 2017). The type of vegetation influences the distribution of organic carbon content in the soil profile. In the $1 \mathrm{~m}$ layer of meadow and forest soils, ca. $42 \%$ and $50 \%$ of carbon, respectively, is accumulated in the surface layer with depth of $0.2 \mathrm{~m}$

Soil type and texture have a significant impact on the content of organic matter, because they determine the water-air conditions that are remarkably important for the intensity of degradation processes. For example, high rate of organic matter decomposi- 
tion is typical for sandy soils, which have lower water retention and higher aeration in comparison to the soil with heavier granulometric composition (Koven et al., 2017).

The content of organic matter is also significantly affected by the chemical stabilization of organic matter, which is correlated with a clay content (Torn et al., 1997). This is due to the occurrence of chemical or physicochemical bonds between the organic substance and clay minerals, making it more resistant to the mineralization processes.

Due to the seasonal time-changing impact of soilforming factors, the properties of soils in natural habitats remain in a state of relative equilibrium. In the soils of natural ecosystems, the inflow and mineralization of organic matter remain in a steady state for hundreds or thousands of years (Wardle et al., 1997). However, this balance can be disturbed by the human activity, leading to significant soil carbon losses in a relatively short time (Post and Kwon, 2000; Strassmann and Fischer, 2008). It was noted that after including the soils into agricultural use, especially when they are used as arable soils, the immediate and rapid reduction of soil organic matter appears. According to Mann (1986) the organic C losses can be up to $40 \%$ in 20 years, half of which is observed in the first 5 years. This pattern can occur regardless of the climate conditions, soil and vegetation types. There are several mechanisms leading to the carbon content decrease in the arable soils: (1) in these soils, compared to the natural ones, there is a smaller inflow of fresh organic matter, since a significant part of the produced biomass is removed from the ecosystem in the form of a crop (Imhoff et al., 2004); (2) the chemical composition of the crop biomass differs from the native vegetation in terms of the $\mathrm{C}$ content in mineralization-resistant buds crop biomass contains low amount of this form of carbon (Kong et al., 2005); (3) changes in the soil physical properties caused by mechanical cultivation (higher aeration) accelerate mineralization (Collins et al., 2000), and as a result of intensive mineralization, more labile $\mathrm{C}$ fractions are created, which are more susceptible to degradation, because they do not form connections with clay minerals (Six et al., 2000); (4) the lack of plant cover in the fields causes significant $\mathrm{C}$ losses due to the increased water and wind erosion (Trimble and Crosson, 2000).

In general, the rate of organic carbon content decrease slows down when the soil organic matter levels reach a state of new equilibrium, which depends on the cultivation system (West and Post, 2002) and the amount of organic matter supplied to the soil in the form of crop residues and organic fertilizers (Kirchmann et al., 2004).

\section{Strategies for increasing the soil carbon stocks}

The factors promoting carbon sequestration in the soil can be divided into two groups: (i) that increase ing the inflow of fresh organic matter - a substrate for humus formation, and (ii) that reducing the losses of humus compounds (Fig. 1). The losses of humus in soil are caused by the mineralization and erosion processes. The factors limiting the losses include: cultivation type - conservation tillage and no-till farming, regulation of soil and water conditions, and, the introduction of ground-cover plants on the soil threatened by erosion. The increase in the biomass inflow may result from an increase in soil productivity, changes in the cultivation system, proper selection of fertilizers and the crop rotation plants. In addition, the change in land use - such as afforestation, permanent grassland or reclamation of degraded soil - increases the global carbon sequestration in soil (Wiesmeier, 2019).

Afforestation of marginal (poor quality) lands is considered an effective way to increase the carbon sequestration (IPCC, 2013; Lamb et al., 2005). The potential for $\mathrm{C}$ sequestration by afforestation of marginal soils depends on the local climatic conditions and the species of the planted trees, and equals to 3 $\mathrm{Tg}$ C/yr in Norway, $6 \mathrm{Tg}$ C/yr in New Zealand, $9 \mathrm{Tg}$ C/yr in Sweden, $107 \mathrm{Tg} \mathrm{C} / \mathrm{yr}$ in Russia and $117 \mathrm{Tg}$ $\mathrm{C} / \mathrm{yr}$ in the USA (IPCC, 2013). Special attention is paid to the renewal of degraded tropical forests (Lamb et al. 2005). Lal (2005) estimates that 350 Mha of tropical forests have been converted to land used in another way, and the next 500 Mha have been degraded to varying degrees.

Improvement of the carbon sequestration in soils can be achieved by changing the soil use type. The results of fields study showed that 20-40 years after the conversion of arable land to grassland the organic carbon content in the top 0-30 cm soil layer was increased by about $20 \mathrm{Mg} \mathrm{C} / \mathrm{ha}$ (Conant et al. 2001). The opposite practice involving the conversion of permanent pasture into arable land resulted in the loss of $40 \%$ of the original SOC resources within 25 years (Poeplau et al., 2011). Renewing the forest on degraded areas can significantly increase the Earth's carbon pool (Lal, 2005).

Integrated nutrient management has a significant impact on the efficiency of carbon sequestration in agroecosystem (Lal, 2004). The intensity and direction of transformation of the humus compounds in soil is affected by the availability of minerals such as N, P, S, Mg and Ca (Hines 1998). The lack of these elements can seriously disturb the transformation of organic matter leading towards the intensification of mineralization and inhibition of humification process. Paustaian et al. (1997) showed that the C:N ratio significantly influences the intensity of $\mathrm{C}$ sequestration in soil. Too high $\mathrm{C}: \mathrm{N}$ may inhibit sequestration. Thus, an increase of the rate of this process in soil can be achieved by nitrogen fertilization. Liebig et al. (2005) indicated that fertilization with high doses of $\mathrm{N}$, compared to non-fertilized soil, increased the $\mathrm{C}$ sequestration by $1.0-1.4 \mathrm{MgC} /(\mathrm{ha} \cdot \mathrm{yr})$. 


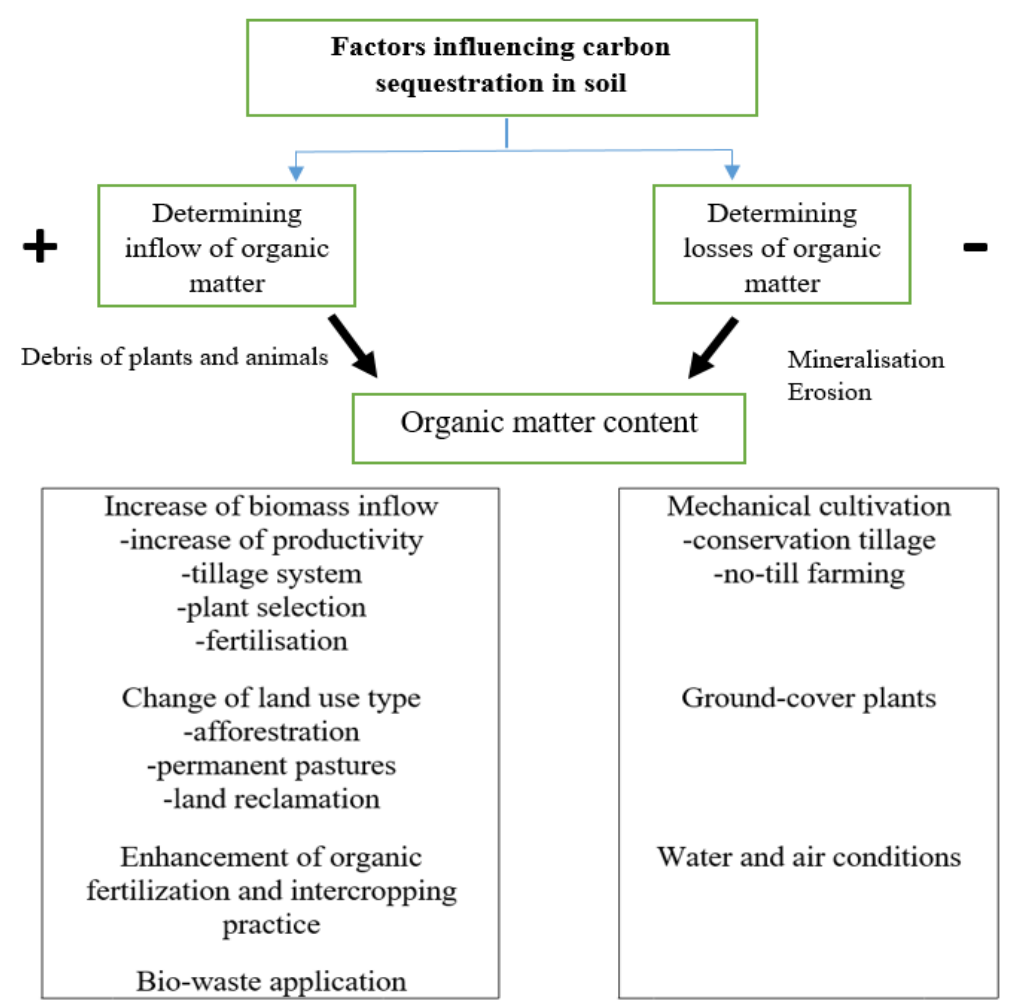

Fig. 1. Factors influencing carbon sequestration in soil

The direct effect of mineral nitrogen on the $\mathrm{C}$ sequestration is connected with the growth of the humification rate, while the indirect one is related to the increase of biomass yields that leads to an increase in the loading of biomass being the substrate for humus formation. The intensity of SOC sequestration depends both on the frequency and the chemical forms of nitrogen used for soil fertilizing.

The influence of mineral nitrogen on the rate, and hence the direction, of the organic matter transformation in soil is reflected not only in the content, but also in the quality of the newly formed humus compounds (Dorado et al., 2003). Cvetkov et al. (2010) indicate the special importance of nitrogen fertilization when using green manure and straw. The addition of mineral nitrogen to the plant residues introduced into the soil accelerates their decomposition, optimizes the use of released nutrients and promotes the formation of more persistent organic substances. Organic fertilization plays a significant role in the strategy of carbon sequestration in the arable soils. The organic carbon content in the soils fertilized with manure is significantly higher compared to the non-fertilized soils and the soils fertilized with NPK (Jenkinson, 1990; Witter et al., 1993; Christensen, 1996; Korschens and Muller, 1996). Nevertheless, the contradictory opinion on the impact of manure can be found. For example, Gong et al. (2009) noted the increase in the soil organic matter (SOM) content, while Simon (2008) observed the stabilization of SOM or SOC in the soil fertilized with manure. The diversity of the results should be attributed to the impact of the factors regulating the conversion of organic matter in the soil (e.g. soil type, climate conditions, plant selection). Most of the cited authors showed that the increase in the content of organic matter in soils is proportional to the dose of manure, and it is observed primarily in the soil layer up to 30 $\mathrm{cm}$. The results of many years of fertilization experiments in Europe clearly indicate an increase in the SOC pool at a depth of $0-30 \mathrm{~cm}$ under the influence of manure, compared to mineral fertilizers; however, the extent of the increase was different in particular countries: in Denmark, the sequestration of $\mathrm{C}$ was $10 \%$ higher in 100 years (Christensen, 1996), in Germany by $22 \%$ in 90 years (Korschens and Muller, 1996), in United Kingdom (Rothamsted) by $100 \%$ in 144 years (Jenkinson, 1990), and in Sweden by $44 \%$ in 31 years (Witter et al., 1993). Additionally, the changes in the SOM content due to the manure application were accompanied by the changes in the humus quality indicators. Schulten and Leinweber (1991) showed that the content of lignin and fatty acids is higher in the soil fertilized with manure compared to the non-fertilized soil. Within the humus compounds found in the soils fertilized with manure, an increase in the humic acid content was observed. At the unchanging content of fulvic acids, this increase resulted in the growth of the ratio of carbon contained in particular acid forms $\left(\mathrm{C}_{\mathrm{H}}: \mathrm{C}_{\mathrm{F}}\right.$ ratio) (Dorado et al., 2003; Cvetkov et al., 2010). Gregorich et al. (1997) showed a smaller share of $\mathrm{C}$ bound in the aromatic compounds in the total amount of $\mathrm{C}$ associated with the clay fraction in the soils fertilized 
with manure. In the elemental composition of the humic acids found in the soils permanently fertilized with manure, insignificantly lower contents of $\mathrm{C}$ and $\mathrm{O}$, higher content of $\mathrm{H}$ and $\mathrm{N}$, lower internal oxidation degree, and higher number of functional groups were observed, compared to the humic acids sampled from the non-fertilized and NPK fertilized soils (Watanabe et al., 2007).

Different bio-waste, including sewage sludge, compost, green waste can be used as the source of external organic matter. Diacono and Mantemuro (2010) report that $8.1 \%, 4.2-6 \%, 3.8 \%$, and $3.7 \%$ of carbon introduced with manure, sewage sludge, composts and straw biomass, respectively, was sequestered in soil.

The impact of crop residues (straw) on increasing the SOC resources is well documented (Neill, 2011). Many researchers underline the complexity of straw decomposition in soil, which depends on the chemical properties of biomass, soil conditions, including temperature and humidity which determine the biological activity. A direction of the plant residues conversion is largely determined by the value of $\mathrm{C} / \mathrm{N}$ ratio, and the content of easily degradable compounds. The plants contain usually the same groups of compounds, but differ in quantitative composition, e.g. maize straw is characterized by a high proportion of hemicelluloses and starch (42\%), alfalfa biomass proteins (16\%), and wheat straw - cellulose (42\%). The research of Lemke et al. (2010) showed that the post-harvest residues of alfalfa, followed by wheat and maize, undergo the transformation processes the fastest.

Wiesmeier et al. (2019) underline the significant role of selection the plant species used in the crop rotation and ground-covering in the increase of the SOC content. West and Post (2002) showed the increase in the organic $\mathrm{C}$ content in the soil with permanent crop rotation system compared to monoculture, in continuous cropping in relation to the system of 3year crop rotation - fallow, and in the crop rotation with a large variety of cultivated plants. The researchers, based on global databases (67 years of experience), stated that increasing the crop diversity can cause significant accumulation of organic matter and achieving a new state of equilibrium after 40-60 years.

The appropriate selection of the plant species in the crop rotation increases the stability of soil structure, the efficiency of nutrient and water uptake, and the crop yielding. Particularly beneficial effects on the improvement of carbon balance and soil properties were noted in the crops in which the papilionaceous plants, capable of binding the atmospheric nitrogen, were included (Mazzoncini et al., 2011).

Involvement of intercrops as green fertilizers and ground cover plants into the crop rotation increases soil richness in organic matter (Bryant 2013). The intercrops are harvested for fodder or plowed as green manure before sowing the next plant. The ground cover plants also increase the inflow of organic residues to the soil that are the starting material for humification. Moreover, these plants increase biodiversity as well as reduce the losses caused by erosion and stress associated with lack of water (Lal 2004). Poeplau and Don (2015), while analyzing the literature data, showed that the average annual SOC sequestration under cover crop conditions was from $0.32 \mathrm{Mg} /(\mathrm{ha} \cdot \mathrm{yr}$ ), which corresponds to the values measured for the soil fertilized with manure and similar to the soil from the arable land changed into the forest. Additionally, they showed that carbon sequestration is long-term (potentially over 100 years), and that $50 \%$ of the total impact of cover crops on the SOC stocks will become apparent in the first two decades. The relatively high sequestration ratio combined with the large surface areas of the agricultural lands that can be potentially available for covering by the plants, enable to state that these practices are a sustainable and effective means of mitigating the climate change.

On arable land, tillage is of key importance for the level of carbon sequestration. Negative SOC balance is recorded on the soils with traditional tillage (plowing). The conservation tillage and no-till (nonplowed) farming favor the soil carbon sequestration. The simplified cultivation techniques (shallow cultivation without turning the furrow) reduce the soil aeration and limit mineralization of organic matter. If the inflow of carbon to soils increases, e.g. due to leaving all the crop residues in the field, an improvement in the carbon balance in soil can be expected (ECCP, 2003). Continuous implementation of this practice for many years may cause that the $\mathrm{C}$ sequestration will take place until the new balance value in soil is established, which will be achieved after about 20-30 years (Lugato et al., 2018). In such a cultivation system, carbon will be more permanently bound in the soils the higher the content of colloidal clay is (Merante et al., 2014). The simplified tillage system with leaving 30 to $70 \%$ of crop residues in the field (conservation tillage) is recommended for non-livestock farms (Ranaivoson et al., 2017).

The transition from traditional tillage to the no-tillage system increases the SOC resources (Mrabet et al. 2001). The no-tillage system affects the SOC resources in two ways: (i) by reducing the disturbances which favor the formation of stable soil aggregates; the aggregates protect the SOC associated with them against an intense mineralization (Six et al., 2000); (ii) by modifying the local edaphic environment (bulk density, pore size distribution, temperature, air-water regime), which may limit the SOC biodegradation (Kay and Vanden-Bygaart, 2002). The rate of accumulation of organic carbon resources in the soils under no-tillage system is estimated at 300-800 kg SOC/(ha·yr) (Paustian et al., 1998). 


\section{Prospective solutions for soil carbon sequestering}

The afore-mentioned practices used in agriculture management can significantly increase the potential of soil for carbon sequestration. This potential can be further increased by new technologies that include precision agriculture, exploitation of unused land resources and the existing biodiversity, plant and microbial biotechnology, and chemical technology. Precision farming uses information technologies that allow adjusting the intensity and timing of agrotechnical operations to the potential demand of plants and field habitat conditions. Over time, the widespread use of precise methods in agriculture can be targeted at the technologies enabling the increase of carbon sequestration in soil. In addition, precision farming can reduce the $\mathrm{CO}_{2}$ emissions to the atmosphere through reduced energy consumption. Metting et al. (2001) indicate that the technological solutions for precision agriculture and forestry should include: development of the sensors detecting the presence of pathogens, which will enable for early application and precise dosing of plant protection products, development of the precision fertilization technology (how much, when and where fertilization is needed) based on the geoinformation systems, developing efficient just-in-time irrigation systems that maximize the water efficiency.

The promising solution for the enhancement of SOC sequestering is the use of native plant species (e.g. resistant to acidification, salinity, drought) in the reclamation of degraded soils (Lal, 2015) and developing the perennial cereals. Perennial grasses selected for breeding, such as wheatgrass, are characterized by deep and extensive root systems. Higher proportion of dry weight allocated underground, compared to the conventional annual crops, is typical for these plants. The supply of organic residues to the soil is much higher than in the case of planting grasses than annual plants. In addition, perennial plants would significantly reduce the need for tillage and reduce the negative impact of this practice on the SOC resources and soil erosion. Larger and deeper root systems can also reduce nitrate leaching to the groundwater and atmosphere (in the form of $\mathrm{N}_{2} \mathrm{O}$ ) (Crews and Rumsey, 2017). Modification of annual plants through targeted breeding and selection in order to increase the accumulation of photosynthesis products in the roots and to obtain varieties with deeper roots system may be another option.

Increasing the soil carbon sequestration can also be achieved by selecting the existing biodiversity and improving microbial-plant symbioses, e.g. mycorrhizal fungi, nitrogen-binding bacteria and the production of soil conditioning microbial inocula (Metting et al., 2001). It would be extremely valuable to develop the ability to obtain the mycorrhizal fungi (and other non-cultured microorganisms) in pure culture. These fungi form symbiotic systems with all the important forest tree species and most of agricultural crops. Mycorrhizal symbiotic systems increase the efficiency of water accumulation and nutrient uptake (phosphorus and microelements). Attention is also paid to the possibility of using the bacterial innocula and humic materials that facilitate the formation and stabilization of soil aggregates. This provides protection against the physical degradation of organic-mineral bindings.

The development of innovative, smart fertilizers and soil quality improvers, as well as the use of plant growth regulators are other potential solutions leading to the increase carbon sequestration in soil. The term smart refers to the fertilizers that release the nutrients in the control way. The future smart fertilizer should be able to release the nutrients in response to the plant demand expressed by sending specific molecular signals.

\section{Conclusions}

The recently observed increase of the GHG concentration, among which $\mathrm{CO}_{2}$ is the most important, causes an enhanced interest in the capture and storage of atmospheric carbon in the soils of various ecosystems as a means of mitigating climate change.

Soils are the largest terrestrial carbon reservoir, and carbon occurs in them in relatively persistent connections, which is why the soils can be treated as a potential $\mathrm{CO}_{2}$ sequestration site.

Increasing the soil carbon resources also brings additional benefits, such as improvement in the physical, physicochemical and biological properties of soils, increase in soil productivity and enhanced ability to perform other ecosystem functions.

Application of adequate agrotechnical measures that favor carbon sequestration in soils can significantly increase the pool of soil organic matter, but the best solutions differ depending on the climate conditions and soil type. Thus, the sustainable land management, suited to the local conditions is crucial for obtaining satisfactory results in long-term carbon storage in soils. Afforestation of poor quality soils, change from arable use for permanent grassland, optimization of plant selection in crop rotation, use of the cover crops, reduction of mechanical soil cultivation by using simplified and no-tillage farming, and application of organic and nitrogen fertilization are the agricultural practices of greatest importance for increasing the potential of agroecosystem soils for carbon sequestration. Adoption of such measures on a large scale seems to be viable and highly efficient, especially when the different practices favoring carbon sequestration are used together. An increase in carbon pool in soil organic matter will not only improve the atmospheric air quality but will also have the positive social and economic outcomes related to the increase of soil fertility and the groundwater quality, as well as to the possibility of managing of different types of organic waste which can be used as a source of external organic matter. 


\section{References}

1. BALESTRINI R., LUMINI E., BORRIELLO R., BIANCIOTTO V., 2015, Plant-Soil Biota Interactions, in: Soil Microbiology, Ecology and Biochemistry (Fourth Edition), Academic Press, p. 311-338.

2. BANWART S.A., BERNASCONI S.M., BLUM W.E.H., DE SOUZA D.M., CHABAUX F., DUFFY C., et al., 2017, Quantifying and managing soil functions in Earth's critical zone - combining experimentation and mathematical modelling. Soil functions in Earth's critical zone: key results and conclusions, in: Adv. Agron., 142, p. 1-27.

3. BATJES N.H., 2013, Reader for the soil carbon benefits module, in: Proceedings of the ISRIC Spring School, April 22-26, 2013, Wageningen University Campus, The Netherlands, p. 1-16.

4. BRYANT L., STOCKWEL, R., WHITE T., 2013, Counting Cover Crops, National Wildlife Federation, Washington DC, https://grasslandoregon.com/assets/ counting-cover-crops.pdf (22.05.2020).

5. BURRAS C.L., KIMBLE J.M., LAL R., MAUSBACH M.J., UEHARA G., CHENG H.H., KISSEL D.E., LUXMOORE R.J., RICE C.W., WILDING LP., 2001, Carbon Sequestration: Position of the Soil Science Society of America, in: Agronomy Publications, 59, p. 1-4.

6. CEL W., CZECHOWSKA-KOSACKA A., ZHANG T., 2016, Sustainable mitigation of greenhouse gases emission, in: Problemy Ekorozwoju/ Problems of Sustainable Development, 11(1), p. 173-176.

7. CHABBI A., RUMPEL C., KOGEL-KNABNER I., 2009 , Stabilised carbon in subsoil horizons is located in spatially distinct parts of the soil profile, in: Soil Biol. Biochem., 41, p. 256-261.

8. CHRISTENSEN B.T., 1988, Effects of animal manure and mineral fertilizer on the total carbon and nitrogen contents of soil size fractions, in: Biol. Fertil. Soils, 5, p. 304-307.

9. COLLINS H.P., ELLIOTT E.T., PAUSTIAN K., BUNDY L.G., DICK W.A., HUGGINS D.R., SMUCKER A.J.M., 2000, Soil carbon pools and fluxes in long-term corn belt agroecosystems, in: Soil Biol. Biochem., 32, p. 157-68.

10. CONANT R.T., RYAN M.G., ÅGREN G.I., BIRGE H.E., DAVIDSON E.A., ELIASSON P.E., et al., 2011, Temperature and soil organic matter decomposition rates - synthesis of current knowledge and a way forward, in: Glob. Chang. Biol., 17 (11), p. 3392-3404.

11. CONANT R.T., PAUSTIAN K., ELLIOTT E.T., 2001, Grassland management and conversion into grassland: effects on soil carbon, in: Ecological Applications, 11, p. 343-355.

12. CREWS T.E., RUMSEY B.E., 2017, What agriculture can learn from native ecosystems in building soil organic matter: A review, in: Sustainability, 9(4), p. 578.

13. CVETKOV M., ŠANTAVEC I., KOCJAN AČKO D., TAJNŠEK A., 2010, Soil organic matter content according to different management system within long-term experiment, in: Acta Agric. Slovenica, 95, p. 79-88.

14. DAVIDSON E.A., JANSSENS I.A., 2006, Temperature sensitivity of soil carbon decomposition and feedbacks to climate change, in: Nature, 440(7081), p. 165-173.
15. DIACONO M., MONTEMURRO F., 2010, Long term effect of organic amendments on soil fertility. A Review, in: Gron. Sustain. Dev., 30, p. 411-422.

16. DIXON R.K., BROWN S., HONGHTON R.A., SOLOMON A.M., TREXLER M.C., WIŚNIEWSKI J., 1994, Carbon pools and flux of global forest ecosystems, in: Science, 263, p. 185-190.

17. DOBRZAŃSKI H., ZAWADZKI S. (eds.), 1995, Gleboznawstwo, 1995, PWRiL, Warszawa

18. DOETTERL S., SIX J., VAN OOST K., CASANOVA-KATNY A., BOUDIN M., BOECKX P., STEVENTS A., MERCKX R., CASANOVA M.A., MUÑOZ C., ZAGAL E., 2015, Soil carbon storage controlled by interactions between geochemistry and climate, in: Nat. Geosci., 8(10), p. 780-783.

19. DORADO J., ZANCADA M.C., ALMENDROS G., LO'PEZ-FANDO C., 2003, Changes in soil properties and humic substances after long term amendments with manure and crop residues in dryland farming systems, in: Journal of Plant Nutrition and Soil Science, 166, p. 31-38.

20. ECCP, 2003, European Climate Change Programme, Final Report of Working Group: Sinks Related to Agricultural Soils https://ec.europa.eu/clima/sites/clima/ files/eccp/second/docs/finalreport_agricsoils_en.pdf (23.05.2020).

21. EEA 2017, Soil, land and climate change, https:// www.eea.europa.eu/signals/signals-2019-content-list /articles/soil-land-and-climate-change (5.06.2020).

22. GOH K.M., 2004, Carbon sequestration and stabilization in soils. Implications for soil productivity and climate change, in: Soil Science and Plant Nutrition, 50(4), p. 467-476.

23. GONG W., YAN X.Y., WANG J.Y., HU T.X., GONG Y.B., 2009, Long-term manuring and fertilization effects on soil organic carbon pools under a wheat-maize cropping system in North China Plain, in: Plant and Soil, 314, p. 67-76 DOI:10.1016/s0038-0717(03)00186-x

24. GREGORICH E.G., CARTER M.R., DORAN J.W., PANKHURST C.E., DWYER L.M., 1997, Biological attributes of soil quality, in: Dev. Soil Sci., 25, p. 81-113.

25. HANSEN J., KHARECHA P., SATO M., MASSONDELMOTTE V., ACKERMAN F., BEERLING D.J, et al., 2013, Assessing 'Dangerous Climate Change': Required reduction of carbon emissions to protect young people, future generations and nature, ed. Añel J.A., in: PLOS One, 8(12), p. 1-26.

26. HINES R., 1991, On Valuing Nature. Accounting, in: Auditing \& Accountability Journal, 4(3).

27. IMHOFF M.L., BOUNOUA L., RICKETTS T., LOUCKS C., HARRISS R., LAWRENCE W.T., 2004, Global patterns in human consumption of net primary production, in: Nature, 429, p. 870-873.

28. IPCC, 2018, Global Warming of $1.5^{\circ} C$. Special Report, https://www.ipcc.ch/sr15/ (12.04.2020).

29. IPCC, 2000, Land Use, Land-Use Change, and Forestry, eds. Watson R.T., Noble I.R., Bolin B., Ravindranath N.H., Verado D.V., Dokken D.J., Cambridge University Press, UK, https://ww www.ipcc.ch/repo $\mathrm{rt} /$ land-use-land-use-change-and-forestry/ (10.04.2020).

30. IPCC, 2013, Climat change 2013: The Physical Science Basis, http://www.climatechange2013.org/ report/ (12.04.2020). 
31. JENKINSON D. S., 1990, The turnover of organic carbon and nitrogen in soil, in: Phil. Trans. R. Soc. B, 329, p. 361-368.

32. JOBBAGY E.G., JACKSON R.B., 2000, The vertical distribution of soil organic carbon and its relation to climate and vegetation, in: Ecol. Appl., 10(2), p. 423-436.

33. KAY B.D., VANDENBYGAART A.J., 2002, Conservation tillage and depth stratification of porosity and soil organic matter, in: Soil Till. Res., 66(2), p. 107-118.

34. KIRCHMANN H., HABERHAUER G., KANDELER E., SESSITSCH A., GERZABEK M.H., 2004, Effects of level and quality of organic matter input on carbon storage and biological activity in soil: synthesis of a long-term experiment, in: Global Biogeochem. Cyc., 18, p. 247-259.

35. KONG A.Y.Y., SIX J., BRYANT D.C., DENISON R.F., VAN KESSEL C., 2005, The relationship between carbon input, aggregation, and soil organic carbon stabilization in sustainable cropping systems, in: Soil Sci. Soc. Am. J., 69, p. 1078-1085.

36. KORSCHENS M., MULLER A., 1996, The static experiment Bad Lauchst dt. Germany, in: Evaluation of soil organic matter: models using existing datasets, eds. Powlson D.S., Smith P., Smith J.U., Nato ASI Subseries I, 38, p. 369-387.

37. KOVEN C.D., HUGELIUS G., LAWRENCE D.M, WIEDER W.R., 2017, Higher climatological temperature sensitivity of soil carbon in cold than warm climates, in: Nat. Clim. Chang., 7, p. 817-822

38. KUNDU S., BAHATTACHARYYA S.K.R., PRAKASH V., GHOSH B.N., GUPTA H.S., 2007, Carbon sequestration and relationship between carbon addition and storage under rainfed soyabean-wheat rotation in sandy loam soil of the Indian Himalayes, in: Soil Till. Res., 92(1-2), p. 87-95.

39. LAL R., 2004, Soil carbon sequestration to mitigate climate change, in: Geoderma, 123(1-2), p. 1-22.

40. LAL R., 2005, Soil carbon sequestration in natural and managed tropical forest ecosystems, in: J Sustain For., 21, p. 1-30.

41. LAL R., 2008, Carbon sequestration, in: Phil Trans $R$ Soc B, 363(1492), p. 815-830.

42. LAL R., 2015, Sequestering carbon and increasing productivity by conservation agriculture, in: Journal of Soil Water Conservation, 70(3), p. 55-62.

43. LAMB D., ERSKINE P., PARROTTA J., 2005, Restoration of degraded tropical forest landscapes, in: Science, 310, p. 1628-1632.

44. LEMKE R.L., VANDENBYGAART A.J., CAMPBELL C.A., LAFOND G.P., GRANT B., 2010, Crop residue removal and fertilizer $\mathrm{N}$ : effects on soil organic carbon in a long-term crop rotation experiment on a Udic Boroll, in: Agriculture, Ecosystems \& Environment, 135 , p. 42-51.

45. LIEBIG M.A., MORGAN J.A., REEDER J.D., ELLERT B.H., GOLLANY H.T., SCHUMAN G.E., 2005, Greenhouse gas contributions and mitigation potential of agricultural practices in northwestern USA and western Canada., Soil Tillage Res., 83, p. 25-52.

46. LUGATO E., LEIP A., JONES A., 2018, Mitigation potential of soil carbon management overestimated by neglecting $\mathrm{N}_{2} \mathrm{O}$ emissions, in: Nature Climate Change, 8, p. 219-223.
47. MANN L.K., 1986, Changes in soil carbon storage after cultivation, in: Soil. Sci., 142, p. 279-288.

48. MAZZONCINI M., SAPKOTA T.B., BÀRBERI P., ANTICHI D., RISALITI R., 2011, Long-term effect of tillage, nitrogen fertilization and cover crops on soil organic carbon and total nitrogen content, in: Soil Tillage Res., 114, p. 165-174.

49. MERANTE P., DIBARI C., FERRISE R., BINDI M., LESSCHEN P.J., KUIKMAN P., SANCHEZ B., IGLESIAS A.. 2014, Report on critical low soil organic matter contents, which jeopardise good functioning of farming systems. Smart Soil Project. Sustainable farm Management Aimed at Reducing Threats to Soils under climate change, http://smartsoil.eu/fileadmin/www.smartsoil.eu/Deliverables/D2_4_SmartSoi 1_Final.pdf (22.04.2020).

50. METTING F.B., SMITH J.L., AMTHOR J.S., IZAURRALDE R.C., 2001, Science needs and new technology for increasing soil carbon sequestration, in: Climatic Change, 51, p. 11-34.

51. MRABET R., SABER N., EL-BRAHLI A., LAHLOU S., BESSAM F., 2001, Total, particulate organic matter and structural stability of a Calcixeroll soil under different wheat rotations and tillage systems in a semiarid area of Morocco, in: Soil Till. Res., 57, p. 225-235.

52. NEILL C., 2011, Impact of crop residue management on soil organic matter stocks. A modelling study, in: Ecological Modelling 222(15), p. 2751-2760.

53. OLEJNIK T., SOBIECKA E., 2017, Utilitarian technological solutions to reduce $\mathrm{CO}_{2}$ emission in the aspect of sustainable development, in: Problemy Ekorozwoju/ Problems of Sustainable Development, 12(2), p. 173-179.

54. OLSON K.R., 2013, Soil organic carbon sequestration, storage, retention and loss in U.S. croplands: Issues paper for protocol development, in: Geoderma, 195-196, p. 201-206.

55. PAUSTIAN K., COLE C.V., SAUERBECK D., SAMPSON N., 1998, $\mathrm{CO}_{2}$ mitigation by agriculture: An overview, in: Climatic Change, 40(1), p. 135162.

56. PAUSTIAN K., COLLINS H.P., PAUL E.A., 1997, Management controls on soil carbon, in: Soil Organic Matter in Temperate Agroecosystems: Long-Term Experiments in North America, eds. Paul E.A., Paustian K., Elliott E.T., and Cole C.V., CRC Press, Boca Raton, Florida, USA, p. 15-49.

57. POEPLAU C., DON A., 2015, Carbon sequestration in agricultural soils via cultivation of cover crops - A meta-analysis, in: Agriculture Ecosystems \& Environment, 200, p. 33-41.

58. POEPLAU C., DON A., VESTERDAL L., LEIFELD J., VAN WESEMAEL B., SCHUMACHER J., GENSIOR A., 2011, Temporal dynamics of soil organic carbon after land-use change in the temperate zone carbon response functions as a model approach, in: Global Change Biology, 17, p. 2415-2427.

59. POST W.M., KWON K.C., 2000, Soil carbon sequestration and land-use change: Processes and potential, in: Global Change Biology, 6, p. 317-327.

60. RANAIVOSON L., NAUDIN K., RIPOCHE A., AFFHOLDER F., RABEHARISOA L., CORBEELS M., 2017, Agro-ecological functions of crop residues under conservation agriculture. A review, in: Agronomy for Sustainable Development, 37, p. 26. 
61. SCHULTEN H.R., LEINWEBER P., 1991, Influence of long-term fertilization with farmyard manure on soil organic matter: Characteristics of particle-size fractions, in: Biology and Fertility of Soils, 12, p. 8188 .

62. SIMON T., 2008, The influence of long-term organic and mineral fertilization on soil organic matter, in: Soil and Water Res., 3(2), p. 41-51.

63. SIX J., ELLIOTT E.T., PAUSTIAN K., 2000, Soil macroaggregate turnover and microaggregate formation: a mechanism for $\mathrm{C}$ sequestration under notillage agriculture, in: Soil Biol. Biochem., 32(14), p. 2099-2103.

64. STOCKMANN U., ADAMS M., CRAWFORD J.W., FIELD D.J., HENAKAARCHCHIA N., JENKINS M. et al., 2013, The knowns, known unknowns and unknowns of sequestration of soil organic carbon, in: Agriculture, Ecosystems and Environment, 164, p. 80-90.

65. STRASSMANN K.M.F., FISCHER J.G., 2008, Simulating effects of land use changes on carbon fluxes: past contributions to atmospheric $\mathrm{CO}_{2}$ increases and future commitments due to losses of terrestrial sink capacity, in: Tellus B 60(4), p. 583-603.

66. TORN M.S., TRUMBORE S.E., CHADWICK O.A., VITOUSEK P.M., HENDRICKS D.M., 1997, Min- eral control of soil organic carbon storage and turnover, in: Nature, 389, p. 170-173.

67. TRIMBLE S.W., CROSSON P., 2000, U.S. soil erosion rates - myth and reality, in: Science, 289(5479), p. $248-250$.

68. WARDLE D.A., ZACKRISSON O., HORNBERG G., GALLET C., 1997, The influence of island area on ecosystem properties, in: Science, 277, p. 12961299.

69. WATANABE A., KAWASAKI S., KITAMURA S., YOSHIDA S., 2007, Temporal changes in humic acids in cultivated soils with continuous manure application, in: Soil Sci. Plant Nutr., 53(3), p. 535-544.

70. WEISMEIER M., URBANSKI L., HOBLEY E., LANG B., MARIN-SPIOTTA E., et al., 2019, Soil organic carbon storage as a key function of soils - A review of drivers and indicators at various scales, in: Geoderma, 333, p. 149-162.

71. WEST T.O., POST W.M., 2002, Soil organic carbon sequestration rates by tillage and crop rotation: a global data analysis, in: Soil Sci. Soc. Am. J., 66(6), p. 1930-1946.

72. WITTER E, MORTENSSON A.M., GARCIA F.V., 1993, Size of the microbial mass in a long-term field experiment as affected by different $\mathrm{N}$ fertilizers, in: Soil Biol. Biochem., 28, p. 659-669. 